Athens Journal of History - Volume 6, Issue 3, July 2020 - Pages 199-222

\title{
Zodiacal Dating Prehistoric Artworks
}

\author{
By Martin B. Sweatman*
}

\begin{abstract}
Recent work has shown that animal symbols in European Palaeolithic cave art and at two ancient sites in southern Turkey, namely Gobekli Tepe and Catalhoyuk, can be interpreted as star constellations, practically the same constellations we continue to use in Europe today. It appears they were often used to represent dates using precession of the equinoxes, where each animal symbol represents a constellation corresponding to one of the solstices or equinoxes. Here, I trace the evolution of this method for writing dates after Catalhoyuk was abandoned in the $6^{\text {th }}$ millennium BCE through to its last known use in Pictish symbol stones during the $1^{\text {st }}$ millennium $A D$.
\end{abstract}

\section{Introduction}

The recent discovery of Gobekli Tepe has sparked a revolution in our understanding of prehistory, the Palaeolithic - Neolithic transition and the origin of civilisation in west Eurasia ${ }^{1,2,3}$. Prior to its discovery, it was often presumed that the development of agriculture enabled the rise of civilisation. However, according to the earliest radiocarbon dates for the site, Gobekli Tepe was constructed before agriculture was established. And given that Gobekli Tepe can be taken as a signal for the arrival of civilisation, considering its massive and extensive megalithic construction with advanced artistry and symbolism, it appears that civilisation preceded agriculture in this region by quite some margin.

Gobekli Tepe, therefore, poses many questions. The key to answering many of these questions must be an understanding of the symbolism carved into its numerous stone pillars. Recent work has interpreted the animal symbols on the broad faces of its stone pillars in terms of star constellations, finding they encode information such as the date of important events and astronomical observations ${ }^{4}$. Very interestingly, the constellations used appear to be the same, or at least very similar, to many of our modern ones.

*Reader, University of Edinburgh, UK.

1. M. B. Sweatman, Prehistory Decoded (Matador, 2019).

2. O. Dietrich et al., "The Role of Cult and Feasting in the Emergence of Neolithic Communities. New Evidence from Gobekli Tepe, South-Eastern Turkey," Antiquity 86, no. 333 (2012).

3. Giulio Magli, "Astronomy and Architecture at the Roots of Civilization," in Archaeoastronomy (Springer, 2016).

4. M.B Sweatman and D. Tsikritsis, "Decoding Gobekli Tepe with Archaeoastronomy: What Does the Fox Say?," Mediterranean Archaeology and Archaeometry 17 , no. 1 (2017). 
Pillar 43 at Gobekli Tepe is especially important. It is like a prehistoric 'Rosetta Stone', as it allows the decoding of these animal symbols with confidence. The message it bears is very likely the date of the Younger Dryas impact event, a catastrophic cosmic collision, possibly with the Taurid meteor stream, that likely triggered the onset of the Younger Dryas mini ice-age around $10,835 \mathrm{BCE}^{56}$. Quite possibly, it was this event that motivated the construction of Gobekli Tepe, and therefore perhaps the origin of civilisation in western Eurasia 7,8 . In other words, civilisation might have begun nearly thirteen thousand years ago with a cataclysmic cosmic collision, and Pillar 43 is a memorial to this event.

Many of the above statements are controversial. The Younger Dryas impact hypothesis has received sustained criticism from some quarters, despite being supported by overwhelming scientific evidence9. Similarly, the archaeologists working at Gobekli Tepe questioned our decoding of the site, but did not challenge the statistical case that supports it ${ }^{10}$.

Conventionally, it is thought our Western zodiacal symbols and constellations were defined by the Babylonians, or the earlier Sumerians ${ }^{11}$, in the $2^{\text {nd }}$ or $3^{\text {rd }}$ millennium BCE. However, this is just an assumption. All we really know is that these people were aware of this knowledge, which they recorded in their star catalogues. There is no clear evidence they invented these constellations. Likewise, the discovery of precession of the equinoxes is generally attributed to Hipparchus of Ancient Greece in the $2^{\text {nd }}$ century BCE. But again, all we can really say is that this is the latest time by which this effect was known. So, there is no problem in principle with knowledge of the zodiac and precession in much earlier times, along with other astronomical phenomena ${ }^{12}$. It is simply that, until now, there was no convincing evidence for this earlier knowledge. But with the discovery of Gobekli Tepe, that has changed.

5. J. P. Kennett et al., "Bayesian Chronological Analyses Consistent with Synchronous Age of 12,835-12,735 Cal Bp for Younger Dryas Boundary on Four Continents," Proceedings of the National Academy of Sciences of the United States of America 112, no. 32 (2015).

6. R. B. Firestone et al., "Evidence for an Extraterrestrial Impact 12,900 Years Ago That Contributed to the Megafaunal Extinctions and the Younger Dryas Cooling," Ibid.104, no. 41 (2007).

7. M.B. Sweatman, "Catastrophism through the Ages, and a Cosmic Catastrophe at the Origin of Civilisation," Archaeology and Anthropology Open Access 1, no. 2 (2017).

8. Sweatman, Prehistory Decoded.

9. V. T. Holliday et al., "The Younger Dryas Impact Hypothesis: A Cosmic Catastrophe," Journal of Quaternary Science 29, no. 6 (2014).

10. J. Notroff et al., "More Than a Vulture: A Response to Sweatman and Tsikritsis," Mediterranean Archaeology and Archaeometry 17, no. 2 (2017).

11. JH Rogers, "Origins of the Ancient Constellations: 1. The Ancient Mesopotamian Traditions," Journal of the British Astronomical Society 108, no. 1 (1998).

12. B. Hayden and S. Villeneuv, "Astronomy in the Upper Palaeolithic," Cambridge Archaeological Journal 21 (2011). 
Following our decoding of Gobekli Tepe, the same methods were applied to interpret zoomorphic symbolism at Catalhoyuk and in Palaeolithic cave $\operatorname{art}^{13}$. It was found that the ancient zodiac and astronomical knowledge uncovered at Gobekli Tepe had probably been in use for tens of thousands of years already, and probably continued to be used in Neolithic Anatolia. Importantly, a statistical case underpinning this discovery was developed. We found the probability of the null hypothesis, i.e. that the correlations we had discovered could have occurred by pure chance, to be in the region of 1 in 140 million for Pillar 43 at Gobekli Tepe and 1 in 380 million for Palaeolithic cave art, although the value obtained for Pillar 43 is subject to a degree of uncertainty. However, even allowing for this uncertainty, the combined probability is completely negligible, and therefore the zodiacal hypothesis is supported with an extreme level of confidence.

Moreover, we found the Lascaux Shaft Scene, probably the most famous Palaeolithic cave art of all, could be dated using this method to the range 15,300 to $15,000 \mathrm{BCE}$, as these are the only dates consistent with the four animals in the scene (bull, duck, rhino and horse) and the approximate conventional age of the cave. This date range was interpreted as another cosmic collision the with the Taurid meteor stream, and was found to correspond to a significant climate fluctuation evident from the GISP2 ice core record ${ }^{14}$. Moreover, it is now clear that this date range also corresponds to a major population bottleneck in this region (southern France) during the Late Middle Magdalenian period. This is revealed by analysis of radiocarbon dates from many archaeological sites across this region $^{15}$.

Regarding Catalhoyuk, its zodiacal date is based on the four types of animal shrine that appear in its main occupation phase; the bear, bull, ram and leopard ${ }^{16}$. The only date range consistent with these animal symbols is 7200 to $6600 \mathrm{BCE}$, which agrees very well with the known date range of the lower levels of Catalhoyuk in which these shrines are found ${ }^{17} ; 7100$ to 6500 BCE.

Following this earlier work, I show here how zodiacal dating can be applied to more of the world's best-known prehistoric artworks, often obtaining dates with greater precision than established methods. We will consider some of the

13. M. B. Sweatman and A. Coombs, "Decoding European Palaeolithic Art: Extremely Ancient Knowledge of Precession of the Equinoxes," Athens Journal of History 5, no. 1 (2019).

14. Ibid.

15. C. Barshay-Szmidt et al., "New Extensive Focused Ams 14 C Dating of the Middle and Upper Magdalenian of the Western Aquitaine/Pyrenean Region of France (Ca. 19-14 ka cal bp): Proposing a New Model for Its Chronological Phases and for the Timing of Occupation," Quaternary International 414 (2016).

16. I. Hodder, Catalhoyuk: The Leopard's Tale: Revealing the Mysteries of Turkey's Ancient 'Town' (London: Thames and Hudson Ltd., 2011).

17. Sweatman and Coombs, "Decoding European Palaeolithic Art: Extremely Ancient Knowledge of Precession of the Equinoxes." 
world's most famous ancient artworks, including the Pashupati Seal and the Gundestrup Cauldron. The list here is not exhaustive, but representative. I recommend the reader reviews the statistical case supporting this zodiacal dating method, described in detail in earlier work ${ }^{18}$, before proceeding.

\section{Zodiacal Dating of Ancient Artworks}

In the following, it is assumed that the zodiacal theory is correct. Therefore, whenever animal symbols consistent with this ancient zodiac appear in prominent settings with apparent cultic or religious significance, they can be used to provide a date using precession of the equinoxes. The ancient zodiac deduced from Gobekli Tepe, Catalhoyuk and the Lascaux Shaft Scene is given in Figure 1.

Typically, we find that four animal symbols are used to encode a date range, representing the four constellations corresponding to the solstices and equinoxes of a specific year. As this pattern repeats every one-quarter of a great year, or 6443 years, the zodiacal dating method must be used in conjunction with another dating method, like radiocarbon dating, to set the appropriate epoch. Given the extremely wide timescales and locations considered, we should not expect this ancient zodiac to be fixed absolutely; minor local variations are expected.

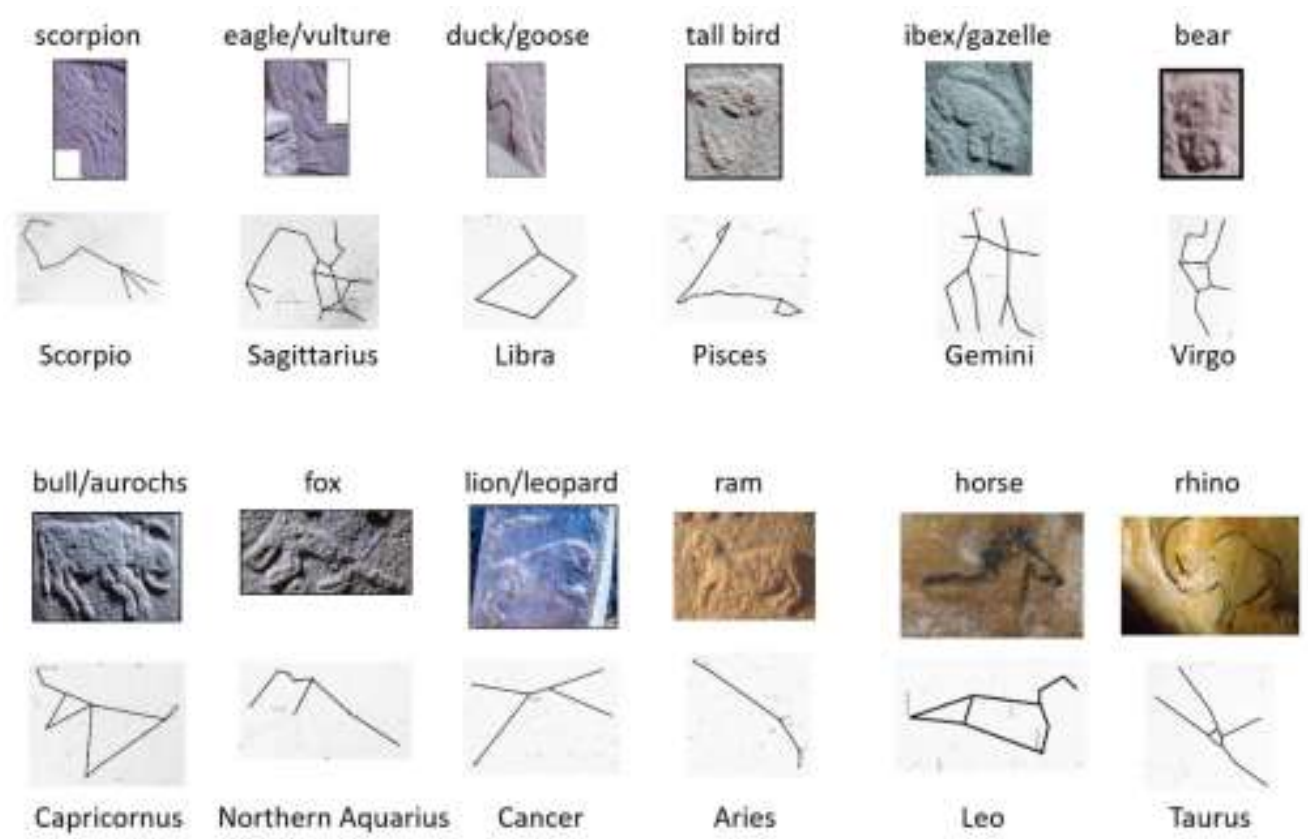

Figure 1. The ancient zodiac deduced from Gobekli Tepe, Catalhoyuk and the Lascaux Shaft Scene

18. Ibid. 


\section{The Nahal Mishmar Treasure Hoard}

Around 1,500 years after Catalhoyuk was abandoned, a community of expert copper smiths stashed their treasure hoard in a cave bordering the Dead Sea of Galilee, near Nahal Mishmar. Their treasure, a collection of copper religious items apparently rescued from the nearby Ein Gedi temple, was wrapped in a reed mat and hidden in a hole in the wall of the cave ${ }^{19}$. Using modern experimental methods, the reed mat has received several radiocarbon dates between $5375 \pm 55$ and $6020 \pm 55 \mathrm{BP}^{20}$, which translates to around 5,200 to 4,050 BCE (95\% confidence using the IntCal13 calibration ${ }^{21}$, although, presumably, the copper items it encloses, which show signs of significant wear and use, are somewhat older.

The largest and most ornate pieces are an extraordinary crown, the earliest known, and sceptre (see Figure 2). Importantly, they display two kinds of prominent animal symbol; ibex on the sceptre and ibex and birds, thought to be vultures with hooked beaks, on the crown. Both animals are included in our ancient zodiac, suggesting, if correctly identified, a zodiacal date range can be estimated. Note that the ibex was a common motif during this period in the Levant, sculpted on ossuaries and painted on pottery, and is suggested to represent a fertility symbol ${ }^{22}$.

Interestingly, the vulture and ibex both appear on Pillar 43 at Gobekli Tepe, were they are thought to represent the summer and winter solstice constellations respectively. But this copper treasure is around 7,000 years, corresponding to about one quarter of a Great Year, younger. This means that here the ibex and vulture likely represent the spring and autumn equinox constellations instead. Using Stellarium ${ }^{23}$, the date range consistent with these constellations, Gemini and Sagittarius respectively, is 6,300 to 4,200 BCE. This overlaps nicely with the radiocarbon age of the mat. Moreover, this reinforces the identification of the ibex with fertility at this time, as it represents the spring equinox constellation. But with only these two animals identified, we cannot provide a more precise date than this for this treasure.

19. D. Ussishkin, "The Chalcolithic Temple in Ein Gedi: Fifty Years after Its Discovery," Near Eastern Archaeology 77 (2014).

20. G. E. Aardsma, "New Radiocarbon Dates for the Reed Mat from the Cave of the Treasure, Israel," Radiocarbon 43 (2001).

21. P.J. Reimer et al., "Intcal13 and Marine13 Radiocarbon Age Calibration Curves 050,000 Years Cal Bp," Ibid.55 (2013).

22 L. Milevski, "A New Fertility Figurine and New Animal Motifs from the Chalcolithic in the Southern Levant : Finds from Cave K-1 at Quleh, Israel," Paleorient 28 (2002).

23 "Stellarium 0.18.0," http://stellarium.org/. 


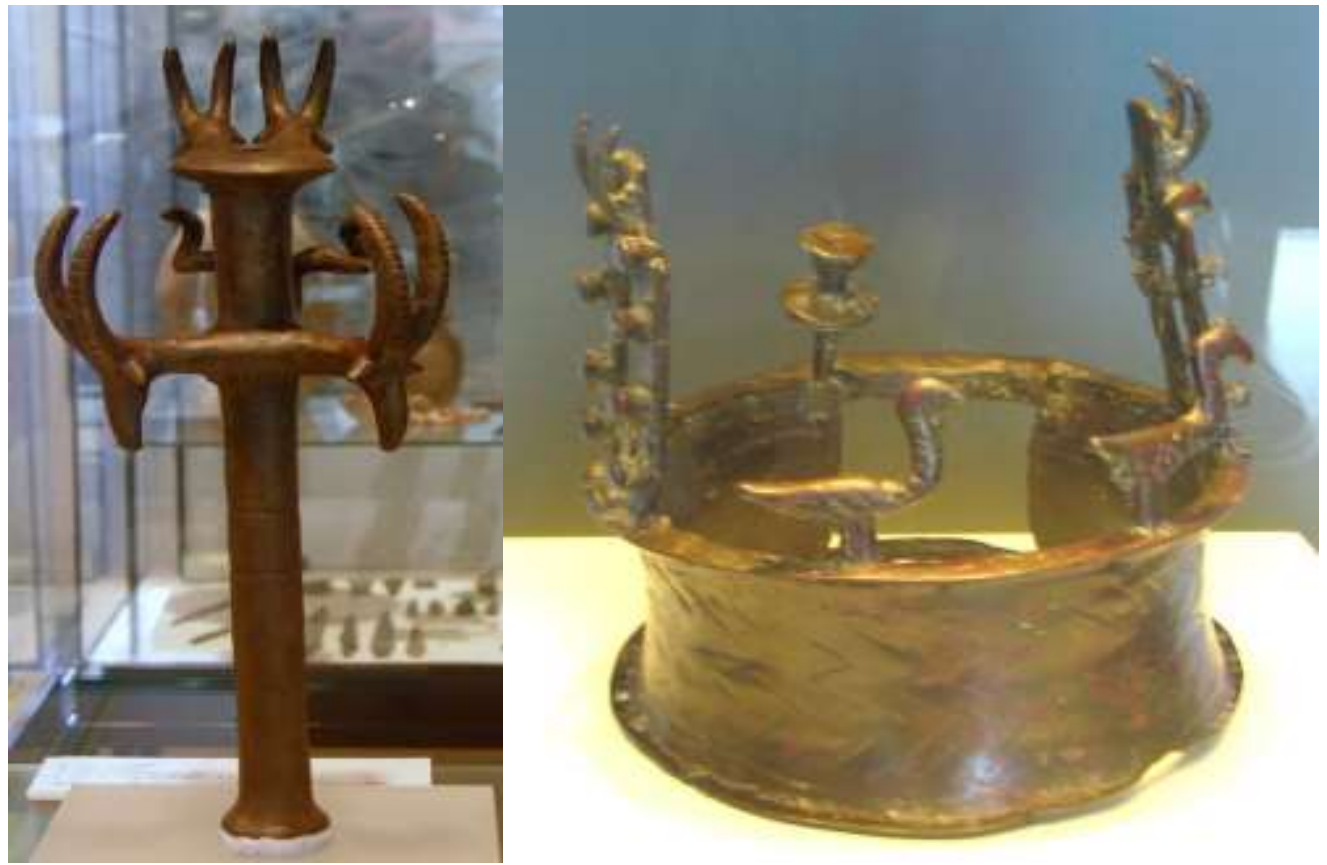

Figure 2. Sceptre and crown from the Nahal Mishmar treasure hoard, images from Wikipedia (Oren Rozen (left) and Hanay (right) [CC BY-SA 3.0])

\section{Origin of the Ancient Egyptian Gods}

One thousand years later we reach the dawn of the great Bronze-Age civilisations of Sumer and Egypt. Proper writing would soon be invented, but it appears the zodiacal system for representing dates continued to be used for several thousand more years.

For example, consider a limestone vase found amongst a cache of important relics at Hierakonpolis by Quibell and Green in 1898 (see Figure 3), including the famous Narmer Palette and Mace, that have been linked with a mythical Scorpion King of predynastic Egypt ${ }^{24,25}$. The animal symbols above the horizontal line on this vase resemble hieroglyphics and can be read as the name "Scorpion King" because the hawk symbol at the top of the vase in later dynastic times refers to the deity Horus, and normally precedes the name of a Pharaoh using the so-called 'Horus name' convention. But the duck/goose symbol at the bottom of the vase is ignored in this interpretation. Dating these artefacts is problematic because the context of their discovery is not well documented. Nevertheless, a date near the end of the $4^{\text {th }}$ Millennium BCE is usually suggested. A desert rock graffiti scene in which a falcon appears above a scorpion, using the same logic, has also been

24 I. Shaw, The Oxford History of Ancient Egypt (Oxford University Press, 2000).

25 S. Hendrickx and R. Friedman, "Gebel Tjauti Rock Inscriptions I and the Relationship between Abydos and Hierakonpolis During the Naqada Iii Period," Gottinger Miszellen 196 (2003). 
linked to a 'scorpion king'26,27. Re-interpretation of this rock graffiti in terms of a date using the zodiacal system will be presented elsewhere.
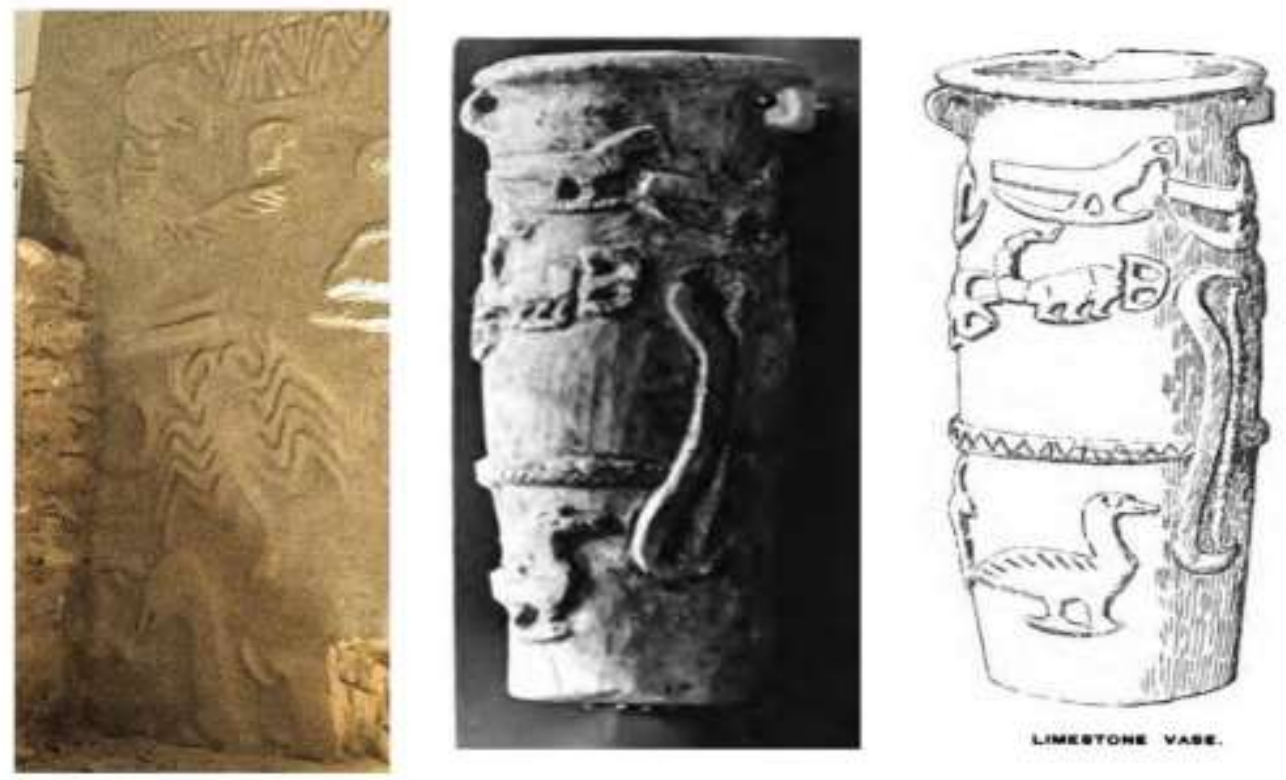

Figure 3. Limestone vase associated with a mythical 'Scorpion King', recovered from Hierakonpolis. Left: reproduction of Pillar 43 from Gobekli Tepe in Sanliurfa museum, courtesy of Alistair Coombs. Right: image from Wikipedia (public domain)

However, we can see that the three symbols on the stone vase are practically identical to those on the main panel of Pillar 43 at Gobekli Tepe, where we see the vertical sequence vulture/eagle, scorpion, duck/goose (see Figure 3). We can, therefore, interpret the symbols on the vase as a date using the zodiacal method. Accordingly, the horizontal line on the vase becomes the horizon, and the vase likely indicates that Libra (represented by the duck/goose) is below the horizon at sunset on the autumn equinox, while the sun is between the constellations of Sagittarius (the hawk) and Scorpius (the scorpion) above the horizon.

This interpretation suggests a new kind of notation, not previously seen, is used on the vase. It appears that when two neighbouring constellations are 'written' together, it indicates that the relevant solstice or equinox is in transition between them. If correct, the vase can be dated using Stellarium quite accurately to around 3,500 BCE (to within 100 years or so), which precedes the estimated date of the cache found in Hierakonpolis by just a few hundred years.

Apart from deducing the date of the vase, this interpretation indicates how hieroglyphic writing developed. That is, it seems to, at least partly, be inspired by

26 Ibid.

27 J.L Le Quellec and D. Huyge, "Rock Art Research in Egypt, 2000 - 2004," in Rock Art Studies, News of the World Iii, ed. P.G. Bahn, N. Franklin, and M. Strecker (Oxford: Oxbow Books, 2008). 
astronomical notation. Moreover, it suggests that the most important Ancient Egyptian deities derived, originally, from constellations. This is sensible, because we know that Ancient Egyptian religion is fundamentally based on astronomy. Moreover, it is already accepted that other Egyptian deities are derived from the stars. For example, Osiris is associated with Orion, while Nut is associated with the night sky, or the milky-way specifically. So, for example, Horus (often represented as a falcon-headed deity), Anubis (dog-headed), Hathor (bovine) and Thoth (represented by a tall bird, like a crane) might derive originally from Sagittarius, Lupus, Capricornus, and Pisces respectively (see Figure 1). Note that these astronomicl-mythological associations are likely very ancient and precede the proto-dynastic period, as indicated by the stone vase above. The known Egyptian asterisms, or decans, were created later during the dynastic period for more utilitarian purposes, such as keeping track of time during the night ${ }^{28}$.

This view is reinforced if we consider symbolism associated with one the most revered Ancient Egyptian deities, Amun29,30. Originally a local god of Thebes, he became the prime creator god for all Egypt in the New Kingdom, in the process absorbing some of the most important aspects of other local gods. His sacred animals are said to be the goose and ram. During his earlier incarnations in the Old and Middle Kingdoms (before the $16^{\text {th }}$ Century BCE) he is sometimes known as the 'great cackler', a 'primeval goose' that laid the 'world-egg' and created the first sound, a myth first attributed to the deity Geb. But in later incarnations, especially during the New Kingdom (16 $16^{\text {th }}$ Century BCE and later), he is commonly linked with the ram, symbolising fertility.

It is probably no coincidence that Libra, symbolised by the duck/goose in our ancient zodiac, is the autumn equinox constellation from around 2300 to 1000 BCE. Moreover, Aries, symbolised by the ram, is the spring equinox constellation from around 1800 to 200 BCE. Once again, we see the spring equinox constellation, here Aries the ram, is associated with fertility.

\section{Pashupati Seal}

The Pashupati Seal, found in the ruins of Mohenjo-Daro, an ancient Indus Valley city, depicts a seated horned god, perhaps an early version of the deity that came to be known eventually as Shiva, surrounded by animals (see Figure 4). This scene is familiar among various Indo-European cultures from the first few

28 J. Lull and J. A. Belmonte, "The Firmament above Thebes: Uncovering the Constellations of Ancient Egyptians," Journal for the History of Astronomy XXXVII (2006).

29 G. Hart, The Routledge Dictionary of Egyptian Gods and Godesses (Routledge, 2005).

30 D. Mackenzie, Egyptian Myths and Legends (Gresham Publishing Co., 1907). 
millennia $\mathrm{BCE}^{31}$. The symbols along the top belong to the, as-yet undeciphered, Indus Valley Script. Notice there are four main animals on this seal, including some from our ancient zodiac. Consequently, we can try to determine a date for this seal using the zodiacal method.

In fact, the four animals here are similar to those in the Lascaux Shaft Scene. We have the bison (or perhaps buffalo on the seal) and rhino, representing Capricornus and Taurus respectively in our ancient zodiac. Immediately, this means the date of this seal must be about one half of a Great Year later than the Lascaux Shaft Scene, i.e. roughly 2000 BC. But instead of the horse, seen at Lascaux, we have the modern feline symbol representing Leo, which means the elephant (or mammoth) on the seal likely represents Libra, like the bird at Lascaux. Using all four constellations, we can read a date range of 2,100 to 1,800 BCE. This is the most precise and accurate dating of this seal, consistent with Mohenjo-Daro's suggested lifespan, 2600 to 1900 BCE $^{32}$.

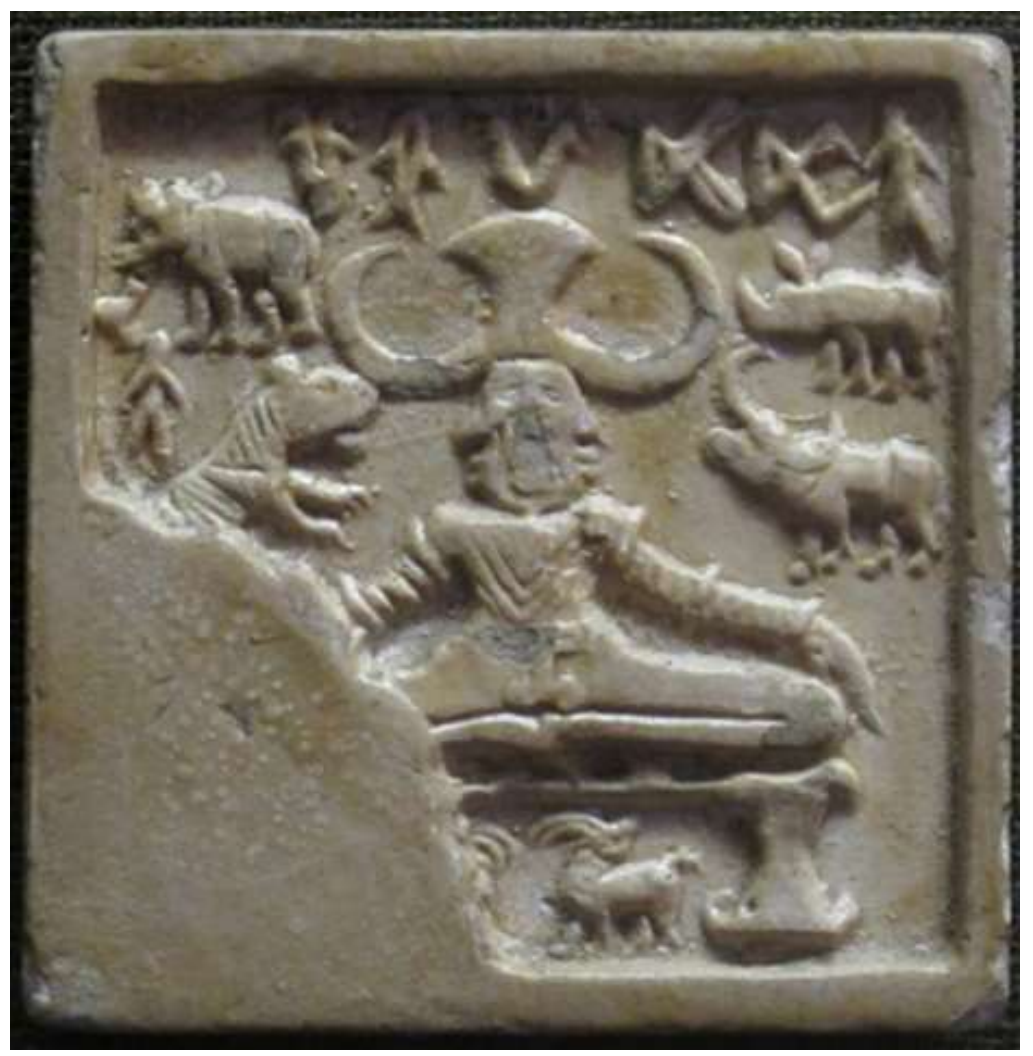

Figure 4. Pressing from the Pashupati seal, image from Wikipedia (Ismoon [CCO])

31 B. A. Olsen, T. Olander, and K. Kristiansen, eds., Tracing the Indo-Europeans (Oxbow Books, 2019).

32. M. J. Kenoyer, "The Indus Valley Tradition of Pakistan and Western India," Journal of World Prehistory 5 (1991). 
Decoding this seal indicates that the ancient zodiac was not fixed, and exhibited minor variations with time and location, as expected. We see from the Pashupati Seal that the feline symbol is switched from representing Cancer to Leo, consistent with our modern Western constellation set. But the elephant/ mammoth is unfamiliar as Libra, and, indeed, has not previously been observed as a zodiacal symbol. Nevertheless, the elephant/mammoth is common in European Palaeolithic cave art. Moreover, if we perform a cross-check with the radiocarbon dates of mammoth paintings in European Palaeolithic cave art, we find they are indeed consistent with the mammoth representing Libra. The only mammoth painting that has been radiocarbon dated and meets our data quality criteria ${ }^{33}$, the painting 'Mammoth 493' from Chauvet cave, has a radiocarbon date of 34,200 $\pm 1,540$ BCE (95\% confidence) and a zodiacal age of 33100 BCE (using Stellarium), taken at the centre of the constellation Libra on the summer solstice. With this additional data point, the null hypothesis for European cave art (see Sweatman and Coombs, 2019) becomes around 1 in 800 million, which provides even greater confidence in the zodiacal hypothesis.

\section{The Gundestrup Cauldron}

Moving forward nearly two millennia and westward to Europe, we find another example of the Indo-European seated horned god surrounded by animals. This time the artwork is preserved in solid silver on the Gundestrup Cauldron (see Figure 5), formed of several large panels, discovered in a bog in Denmark in 1,891 AD. Based on specific artistic motifs, it has been dated to the first few centuries BCE, or thereabouts ${ }^{34}$. Radiocarbon measurement of its age suggests a time-frame between $100 \mathrm{BCE}$ and $200 \mathrm{AD}$ (using the latest IntCal13 calibration curve), although an older age cannot be ruled out ${ }^{35}$. This radiocarbon measurement is thought to be the most reliable of those carried out on aged beeswax still in place on the surface of the cauldron. An older date, 400 to 200 $\mathrm{BCE}$, is obtained by radiocarbon dating of a section of ironwork with entrained charcoal particles remaining from casting the iron.

The panel displaying the classic horned deity, perhaps a representation of the deity known as Cernunnos in this region of Celtic Europe, also displays two bulls, three lions, a fish or dolphin, a stag, and what is probably a hunting dog. The similarity of this scene with the Pashupati Seal suggests this artefact might also be

33. Sweatman and Coombs, "Decoding European Palaeolithic Art: Extremely Ancient Knowledge of Precession of the Equinoxes."

34. F. Kaul, "The Gundestrup Cauldron: Thracian Art, Celtic Motifs," Etudes Celtiques 37 (2011).

35. S. Nielsen et al., "The Gundestrup Cauldron: New Scientific and Technical Investigations," Acta Achaeologica 76 (2005). 
dated by the zodiacal method. Of course, being several millennia younger, the animals on the cauldron are different to those on the Pashupati Seal. It is interesting to observe there are five different kinds of animal in this scene, rather than four, suggesting that one of the solstices or equinoxes might be in transition between two constellations. Here, we are using the convention first observed on the stone vase, described above, found in Hierakonpolis.

The bull probably represents Capricornus on the winter solstice, and the lions probably represent Cancer (consistent with the ancient zodiac) here rather than Leo as on the Pashupati Seal (consistent with our modern one), on the summer solstice. Note how a pair of lions face each other, just like the leopards at Catalhoyuk ${ }^{36}$, reinforcing the view that these felines represent Cancer (as at Catalhoyuk) rather than Leo.

The fish or dolphin probably represents Pisces, consistent with our modern zodiac, replacing the tall bending bird in the ancient zodiac. However, fish are also observed in European Palaeolithic cave art, for example the salmon at Abri du Poisson, although none have been radiocarbon dated. Potentially, then, the fish symbol, representing Pisces, is a very ancient alternative to the bending bird in the ancient zodiac.

With these animals translated to constellations we immediately find using Stellarium a date range from $200 \mathrm{BC}$ to $0 \mathrm{BCE}$, which agrees perfectly with other estimated dates for the cauldron. Before around $200 \mathrm{BCE}$, the spring equinox constellation is Aries (ram) instead of Pisces, and after 0 BCE the winter solstice constellation is Sagittarius (vulture/eagle), rather than Capricornus. Neither the ram nor the vulture/eagle appear on the panel.

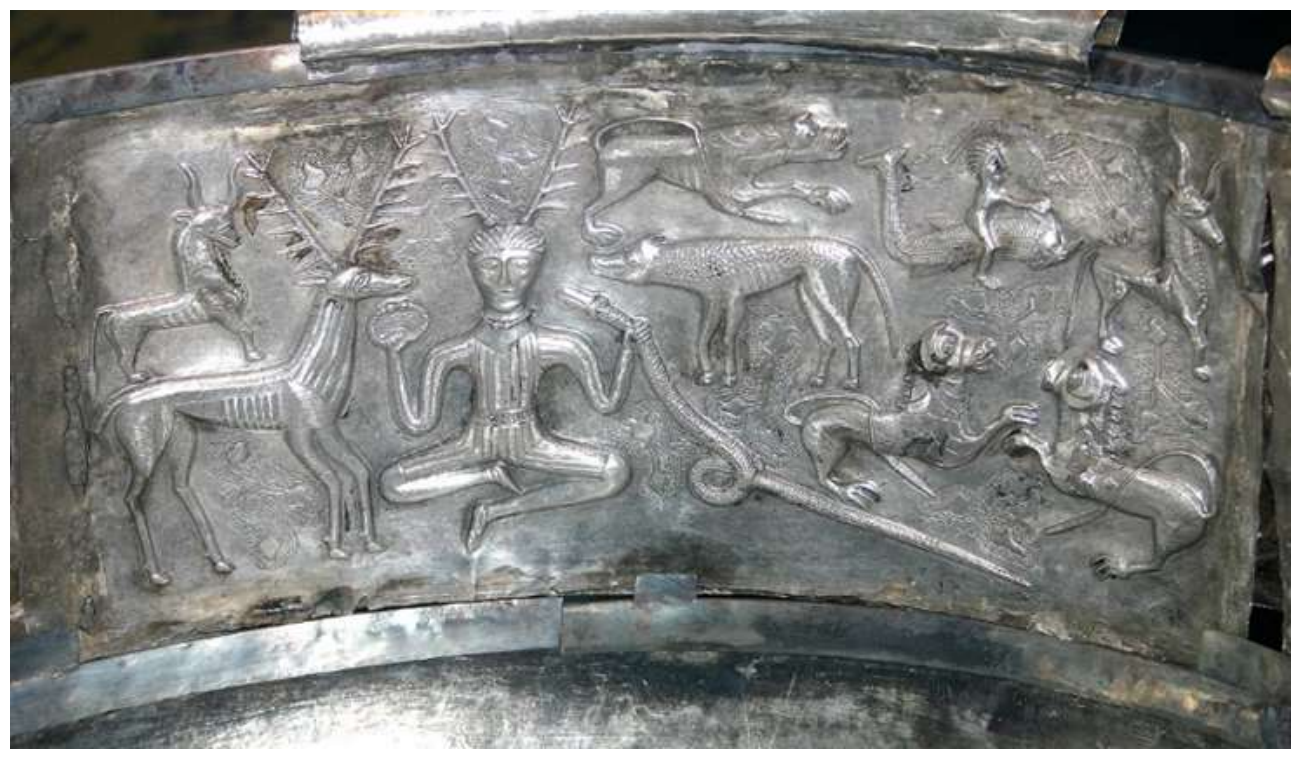

36. Hodder, Catalhoyuk: The Leopard's Tale: Revealing the Mysteries of Turkey's Ancient 'Town'. 
Figure 5. The Gundestrup Cauldron panel featuring a seated horned deity, image from Wikipedia (Malene Thyssen [CC BY-SA 3.0])

The stag and the hunting dog remain to be deciphered. For the date range $200 \mathrm{BC}$ to $0 \mathrm{BCE}$ the remaining symbol should be the bear according to our ancient zodiac (see Figure 1), representing Virgo as the autumn equinox constellation. Note also that over the range $100 \mathrm{BC}$ to $0 \mathrm{BCE}$ the summer solstice constellation is in transition between Cancer and Gemini.

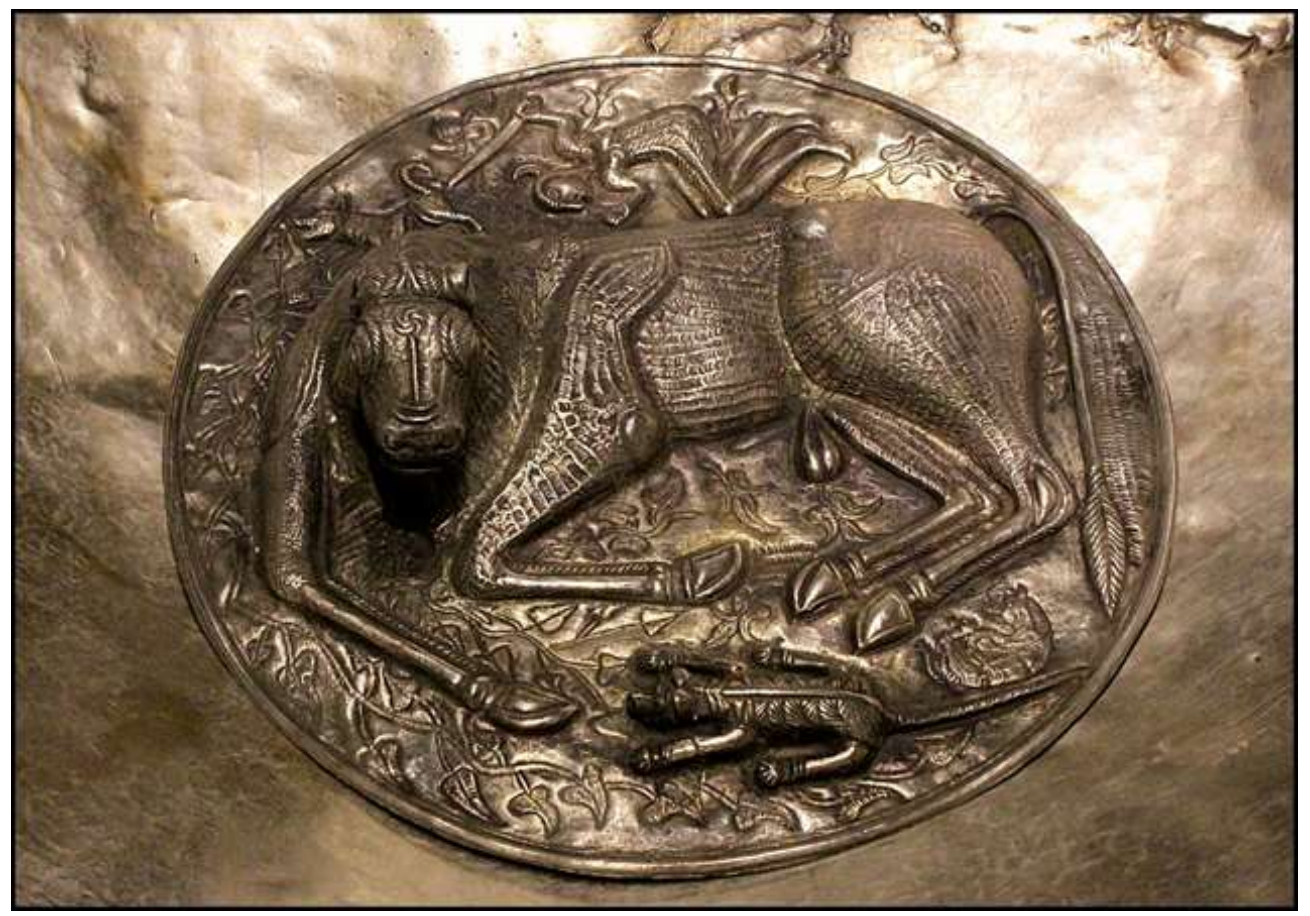

Figure 6. Bottom panel of the Gundestrup Cauldron, image from Wikipedia (Claude Valette [CC BY-SA 3.0])
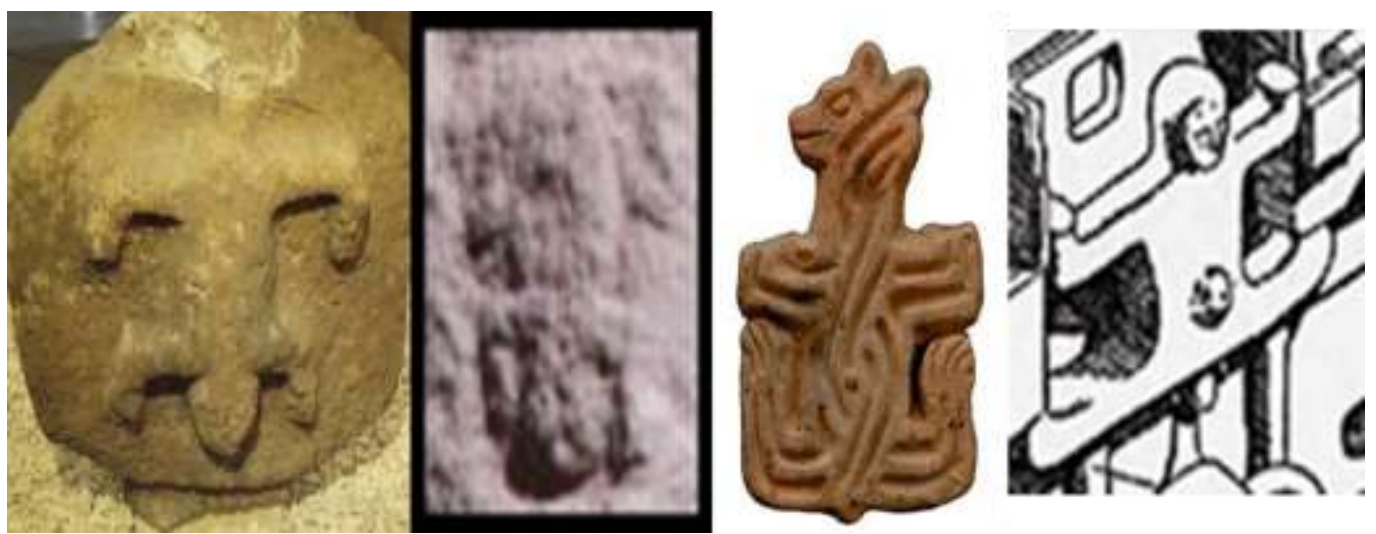

Figure 7. 'Splayed bear' symbols likely representing Virgo. From left to right; on a stone recovered from Gobekli Tepe now in Sanliurfa museum (image courtesy of Alistair Coombs), top-right on Pillar 43 at Gobekli Tepe (image courtesy of Alistair Coombs), a 
seal stamp from Catalhoyuk (from www.catalhoyuk.com), and an artist's impression of a bear shrine at Catalhoyuk (courtesy of Alan Mellaart)

Let's consider the dog first. Clearly, this dog has a similar profile to a bear, albeit a rather slim one, suggesting that this symbol might represent Virgo. This view is reinforced when we consider the bottom of the cauldron. Here, a bull is held at bay by the hunting dog (see Figure 6). But note how this dog has a splayed shape, just like the splayed bear at Gobekli Tepe and Catalhoyuk (see Figure 7). It appears, then, that the hunting dog (or slim bear) does indeed represent Virgo, as expected.

This leaves the stag. One possibility is that the stag represents Gemini, which would narrow down the date of the cauldron to $50 \mathrm{BC}$, to within 50 years. In this case, the feline and stag symbols indicate the summer solstice is in transition between Cancer and Gemini. Of course, it could also be that the stag is not a zodiacal symbol, and its presence here is related somehow to the antlers worn by the deity, considering that until now the ibex has represented Gemini in the ancient zodiac (see Figure 1). However, as we have seen, the ancient zodiac does exhibit some local variations, and it might well be the case that the antlered stag has replaced the horned ibex as Gemini in this region at this time. But until some additional evidence comes to light to corroborate this association, this is quite speculative.

In summary, the zodiacal date for this cauldron is probably either $100 \mathrm{BC}$, to within 100 years, or $50 \mathrm{BC}$, to within 50 years, depending on whether the stag represents Gemini or not. In either case, agreement with other estimated dates for the cauldron is excellent.

\section{Pictish Symbols}

Pictish symbol stones are probably the most recent example of the use of this zodiacal system. Given the close proximity of the Picts to the Celts, with their Gundestrup Cauldron, across the North Sea, it should not be surprising to see the system in use in $1^{\text {st }}$ millennium AD Pictish Scotland.

Over 100 Pictish symbol stones, decorated with symbols, have been recovered, mainly in north-east Scotland. Although it is clear the stones carry information ${ }^{37}$, and are not simply random symbols, they have nevertheless perplexed scholars since their discovery (see Figure 8 for some of the most

37. R. Lee, P. Jonathan, and P. Ziman, "Pictish Symbols Revealed as a Written Language through Application of Shannon Entropy," Proceedings of the Royal Society A 466 (2010). 
common symbols) $)^{38,39}$. However, with the discovery of the ancient zodiac, these Pictish symbols can now largely be understood as astronomical.
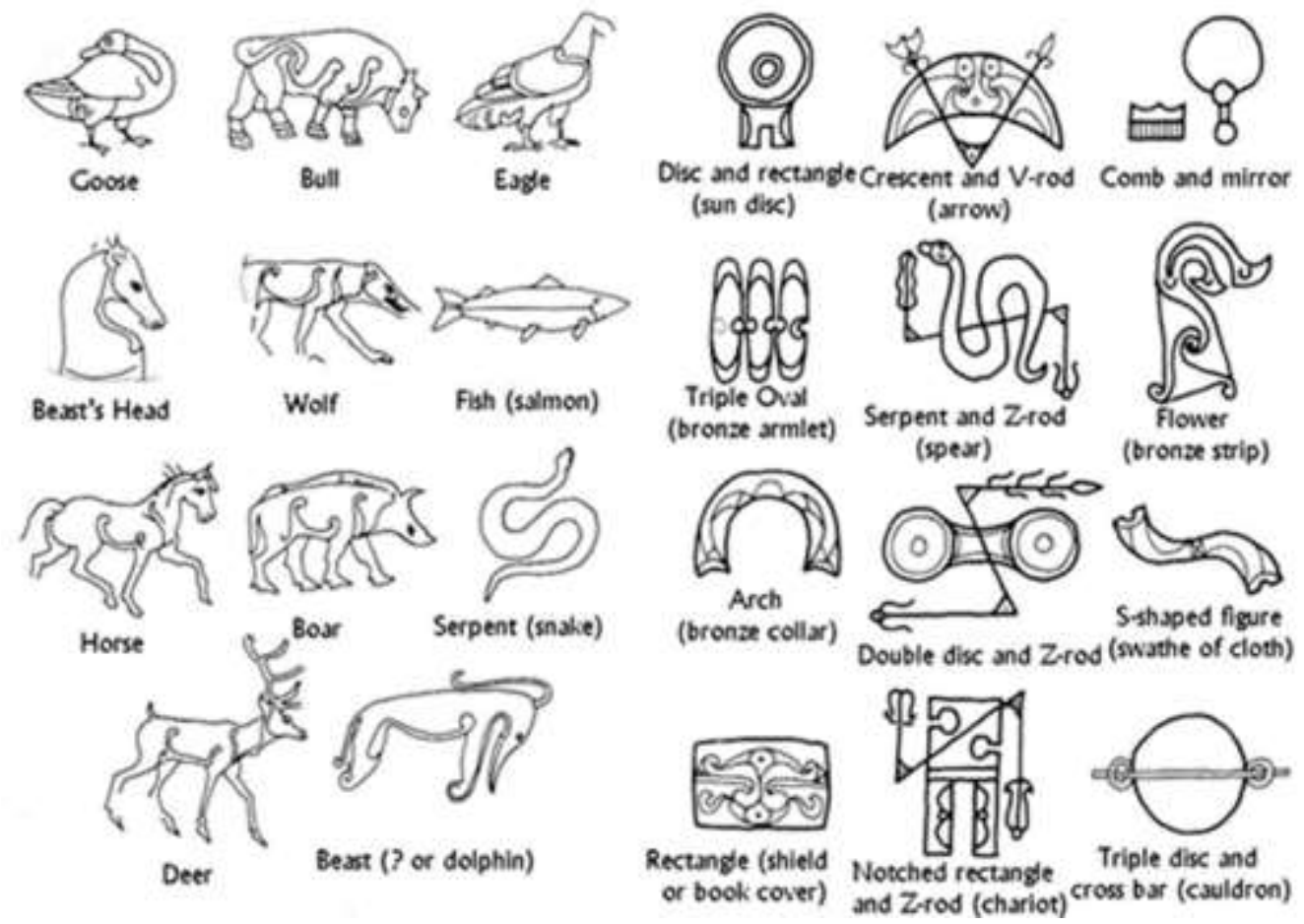

Figure 8. Some of the most common Pictish symbols, courtesy of Aberdeenshire District Council

The earliest stones tend to be relatively simple, usually displaying just two Pictish symbols (Class I), while later ones (Class II and III) can be quite complex, with a variety of Pictish and Christian-influenced patterns. However, if we count how often the various patterns occur on all the stones found, focussing only on the animals, we find the following list.

The most numerous Pictish animal symbol is the 'Pictish beastie' (54 examples according to $\mathrm{Mack}^{40}$ ). Figure 9 compares a drawing of this Pictish symbol directly with the one from Pillar 43 at Gobekli Tepe - the ibex, representing Gemini in our ancient zodiac.

38. A. Jackson, The Symbol Stones of Scotland (Orkney, 1984).

39. W. Cummins, Decoding the Pictish Symbols (The History Press, 2009).

40. A. Mack, A Field Guide to the Pictish Symbol Stones (The Pinkfoot Press, 1997). 

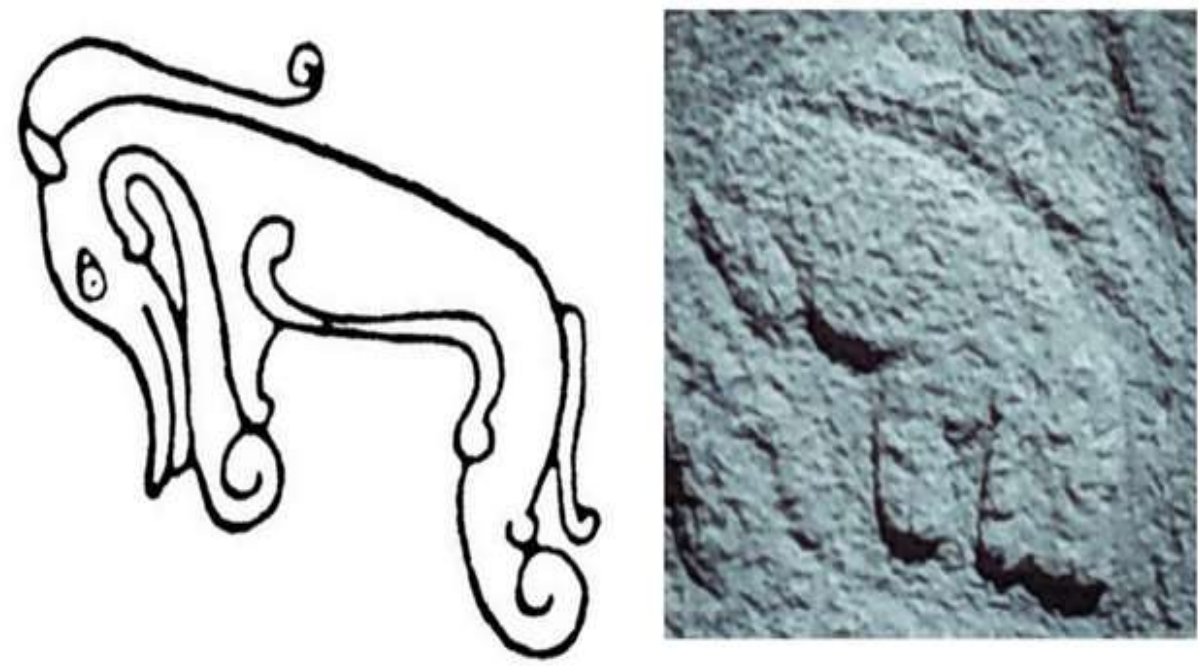

Figure 9. Comparison of the Pictish 'beastie' with the ibex symbol on Pillar 43 at Gobekli Tepe, left image from Wikipedia (Struthious Bandersnatch [CC BY-SA 3.0])), right image courtesy of Alistair Coombs

These symbols appear to be incredibly similar, from the inclination of the head to the 'horns' along the back, although the Pictish symbol seems to have an aquatic character, and indeed is often thought to be a dolphin. Possibly this indicates the Pictish beastie is a mythical 'Aquatic goat' creature. In our modern zodiac, obtained from the Greeks via Mesopotamia, of course the 'Aquatic Goat' symbol represents Capricornus, and not Gemini.

Interestingly, Gemini is the summer solstice constellation from around 100 $\mathrm{BCE}$ to the present day. This suggests that the transition of the ibex from Gemini in the ancient zodiac to Capricornus in our modern one might have occurred in two steps. First, the 'aquatising' of the ibex/goat and then its switch from Gemini to Capricornus. For the Picts, only the first step appears to have taken place.

The next most numerous Pictish animal symbol is the snake, often pierced by a 'z-rod' ( 25 examples in total ${ }^{41}$ ), which also happens to be the most numerous animal symbol at Gobekli Tepe, where it likely symbolises a meteor ${ }^{42}$.

The third most numerous Pictish animal symbol is the fish (18 examples $\left.{ }^{43}\right)$, which following the interpretation of the Gundestrup Cauldron above, can be taken to represent Pisces, just as it does in our modern zodiac. Note that Pisces is the spring equinox constellation from around 200 BCE until the present day.

41. Ibid.

42. Sweatman, Prehistory Decoded.

43. Ibid. 
The fourth most numerous Pictish animal symbol is the eagle (15 examples ${ }^{44}$, which according to our ancient zodiac represents Sagittarius. Again, this agrees with the zodiacal hypothesis because Sagittarius is the winter solstice constellation from $0 \mathrm{BCE}$ until the present day.

The fifth most numerous Pictish animal symbol is the bull (10 examples $\left.{ }^{45}\right)$, but these are found in only one location, Burghhead, and they are always found alone without any other symbols. We will come back to them.

The sixth most numerous Pictish animal symbol is the deer, or at least its head (6 examples ${ }^{46}$ ). Now, we saw from the Gundestrup Cauldron the possibility that the deer, or stag, represents Gemini in the Celtic zodiac of western Europe, replacing the ibex of the ancient zodiac. Their relatively high frequency as Pictish symbols would tend to confirm this. Therefore, it appears that both the Pictish beastie and the stag were used to represent Gemini. Perhaps different ethnic groups with slightly different ancestral zodiacs lived in Scotland at this time, but all have been labelled as Picts.

There is a tie for the seventh most numerous animal symbol between the boar and the dog or wolf (also called the 'beast'), with 3 examples each ${ }^{47}$. Now, we saw from the Gundestrup Cauldron that the hunting dog (or slim bear) probably represents Virgo, which is the autumn equinox constellation from around $1000 \mathrm{BCE}$ to the present day (we are just reaching the transition to Leo). Therefore, the dog or wolf Pictish symbol is also consistent with our zodiacal hypothesis. The boar symbol, on the other hand, is curious. It is one of the most common symbols at Gobekli Tepe, but it is rare in Palaeolithic cave art, and so far we have not been able to interpret it with any confidence.

We now return to the issue of the Burghead Bulls. These bull symbols are unique; they only appear alone on a stone and have only ever been found at Burghead, a small town on the Moray Firth thought to have been founded by the Picts. Indeed, an ancient Pictish fort is found at Burghead, suggesting Burghead is one of the oldest Pictish cultural centres ${ }^{48,49}$. Construction of Burghead Fort is thought to have begun in the $3^{\text {rd }}$ or $4^{\text {th }}$ century $A D$, but there are clear indications of earlier human settlement in the area. Because they appear alone, while all other Pictish symbol stones carry at least two symbols, Cummins did not consider them Pictish symbols at all ${ }^{50}$. However, their style marks them clearly as belonging to the repertoire of Pictish symbols. In fact, their anomalous appearance can also be explained in terms of the zodiacal hypothesis.

44. Mack, A Field Guide to the Pictish Symbol Stones.

45. Ibid.

46. Ibid.

47. Ibid.

48. K. J. Edwards and I. Ralston, "New Dating and Environmental Evidence from Burghead Fort, Moray," Proceedings of the Society of Antiquaries of Scotland 109 (1978).

49. G. Noble and N. Evans, eds., The King in the North (Birlinn Ltd., 2019).

50. Cummins, Decoding the Pictish Symbols. 
To see this, it is first necessary to consider another unique feature of life at Burghead, the 'Burning of the Clavie' festival. This festival is still celebrated each winter by residents of Burghead in early-mid January. It involves carrying the 'Clavie', essentially a giant flaming torch, around the town. The festival, usually held on the $11^{\text {th }}$ Jan, is known to derive from a New Year festival before a change to the Calendar system of the UK took place in the mid eighteenth century. Quite possibly, this New Year celebration derives from an even more ancient winter solstice celebration. Very interestingly, Capricornus, represented by the bull in the ancient zodiac, is the winter solstice constellation from around $2000 \mathrm{BC}$ to $0 \mathrm{BCE}$. Quite possibly, then, the Burghead bulls are the earliest of all the known Pictish symbols, and were used together with the Burning of the Clavie festival at Burghead, one of the earliest Pictish cultural centres, to celebrate the winter solstice in the first millennium BCE. Their early provenance might then explain their anomalous appearance as single symbols on Pictish stones.

Some of the more abstract and geometric Pictish symbols can also be easily related to an astronomical theme, reinforcing the zodiacal hypothesis. For example, the most common symbol of all involves a crescent (the 'crescent and vrod', 86 examples $\left.{ }^{51}\right)$, which clearly symbolises an aspect of the moon, and the third-most common symbol (57 examples ${ }^{52}$ ), the 'double-disc and z-rod', can be interpreted as the switch from a rising to a descending sun or vice-versa, i.e. a solstice. An astronomical interpretation is not yet clear for the second-most common symbol, the 'comb and mirror', involving several circles joined by a line. Likewise, many, but not all, of the remaining Pictish symbols have obvious astronomical interpretations.

\section{Diffusion of the Ancient Zodiac}

The history of archaeological theory can be cast as an intellectual struggle between cultural diffusionists and cultural ecologists ${ }^{53,54}$. The most extreme variant of diffusionism, known as hyper-diffusionism, has a long history and posits that the main cultural elements of many cultures around the world can be traced to a 'mother' culture from which they originated. The main theoretical problem with this idea is one of timescale: how can any cultural trait remain intact over the very long timescales required for cultural diffusion from one corner of the world to another? The assumption here is that prehistoric people

51. Mack, A Field Guide to the Pictish Symbol Stones.

52. Ibid.

53. S. Hakenbeck, "Migration in Archaeology: Are We Nearly There Yet," Archaeological Review from Cambridge 23 (2008).

54. E. A. Storey and T. L. Jones, "Diffusionism in Archaeological Theory," in Polynesians in America: Pre-Columbian Contacts with the New World, ed. T. L.Storey Jones, E. A., E. A. Matisoo-Smith, and J. M. Ramirez-Aliaga (Altamira Press, 2011). 
could only travel slowly by land or along coastal routes, and, moreover, cultural traits diffuse even more slowly than people migrate. Rapid ocean voyages in prehistory are typically ruled out, or at least thought to be relatively insignificant. However, an even greater barrier to this theory has been its historical association with racist ideologies, regardless of whether it is correct or not.

The opposite view of cultural ecology developed from the late 1960s onwards, and in its most extreme form suggests that all cultural traits for all cultures around the world are developed independently in response to local conditions, such as climate and availability of resources. Despite much support within much of the archaeological community in recent decades, presumably as a response to the more extreme versions of diffusionism, it is clearly wrong as it ignores clear evidence in favour of diffusionism.

For example, modern developments into studies of ancient DNA have shown that migration is extremely important, and provides an obvious explanation for many aspects of cultural diffusion. In particular, it is now quite clear that Neolithic European culture was dominated by two massive migration events, namely the migration into Europe of Anatolian 'farmers' around 6000 $\mathrm{BCE}$, and of Indo-Europeans around $3000 \mathrm{BCE}^{55,56,57}$. It is tempting to link the 3000-year gap here to the 3000-year precessional cycle of the Taurid meteor stream $^{58}$.

Following developments in modern scientific methods, such as ancient DNA, archaeological debate has re-focussed on the balance between these two opposing influences; diffusionism versus cultural ecologism. Once one accepts that cultural diffusion that cannot be side-lined, and that migration is an important contributor, it is rational to seek the oldest and most widespread of these diffused cultural traits. Cave art, linguistic and mythological traits are obvious candidates. Moreover, given the evidence presented here, it is rational to seek within any of these long-lasting diffuse cultural traits evidence for the influence of the Taurid meteor stream and its catastrophic consequences.

Palaeolithic cave art has already been discussed. Radiocarbon dating evidence shows very clearly that this specific artistic cultural trait was spread widely across Europe, and perhaps beyond, for over 30,000 years. The similarity in technique and artistic subject over this timescape is direct evidence of longlasting, wide-ranging cultural diffusion. Earlier sections of this work show how this art was likely used, in the case of the Lascaux Shaft Scene at least, to record catastrophic encounters with the Taurid meteor stream.

55. M. E. Allentoft et al., "Population Genomics of Bronze Age Eurasia," Nature 522, no. 7555 (2015).

56. W. Haak et al., "Massive Migration from the Steppe Was a Source for IndoEuropean Languages in Europe," Ibid.

57. Olsen, Olander, and Kristiansen, eds., Tracing the Indo-Europeans.

58. D. J. Asher and S. V. M. Clube, "Towards a Dynamical History of 'Proto-Encke'," Celestial Mechanics \& Dynamical Astronomy 69, no. 1-2 (1997). 
Turning to comparative linguistics next, linguists have developed several major language families, such as Indo-European and Afro-Asiatic, that indicate diffusion of linguistic traits over several thousand years across large, continentalscale areas. Further developments have tried to define super language families that link the major language families further back in time. Although controversial, one of the most well-known of these is the Nostratic super language family, and its minor variants $59,60,61$. The originating language, Proto-Nostratic, is thought to have existed towards the end of the Palaeolithic with an origin near the Fertile Crescent. In line with this idea, Gobekli Tepe would likely have been an important Proto-Nostratic cultural centre. Attempts to go further back in time to unify any potential super language families are generally thought to be unreliable.

Regarding mythology, elements of a Proto-Indo-European (PIE) mythology have been defined and are largely accepted ${ }^{62}$. The main figures of the PIE pantheon are known as the 'sky father' and 'sky-twins', which are clearly very compatible with astronomical phenomena such as comets and their splitting events. The seated horned gods described earlier are likely examples of the PIE sky-father deity. It is therefore tempting to associate these deities with comets and the Taurid meteor stream. That many of the most significant ancient deities derived from comet-worship was already suggested by Clube and Napier63, pioneers of the theory of coherent catastrophism induced by the Taurid meteor stream ${ }^{64,65}$.

Mythology, however, appears to be more robust than language, and many comparative mythologists have tried to establish links between very diverse cultures separated by vast timescales and distances. A recent, comprehensive and ambitious study of this kind by Witzel even provides a history of mythology for the whole world from the time modern humans migrated out of Africa around 65000 years ago $^{66}$. Through his analysis, he detects a transition in mythology,

59. A.C. Renfrew, ed. Nostratic: Examining a Nostratic Macrofamily (McDonald Institute for Archaeological Research, 1999).

60. A. Dolgopolsky, Nostratic Dictionary (McDonald Institute for Archaeological Research, 2008).

61. A. Bomhard, A Comprehensive Introduction Ot Comparative Nostratic Linguistics, 2nd ed. (2015).

62. J.P. Mallory and J.Q. Adams, The Oxford Introduction to Proto-Indo-European and the Proto-Indo-European World (Oxford University Press, 2006).

63. V. Clube and W Napier, The Cosmic Serpent (London: Faber and Faber Limited, 1982).

64. D.J. Asher et al., "Coherent Catastrophism," Vistas in Astronomy 38, no. 1 (1994).

65. S. V. M. Clube and W. M. Napier, "The Microstructure of Terrestrial Catastrophism," Monthly Notices of the Royal Astronomical Society 211, no. 4 (1984).

66. E.J.M. Witzel, The Origins of the World's Mythologies (Oxford: Oxford University Press, 2012). 
apparently around 40000 years ago, that diffused across Eurasia and later found its way to the Americas via Beringia. He calls this ancient mythological system 'Laurasian'. Very interestingly, 40000 years is also the kind of timescale expected for the origin of the Taurid meteor stream.

Witzel's list of the core themes of his ancient Laurasian mythology are repeated below;

1. Father heaven engenders: two generations ('Titans/Olympians').

2. Four (or five) generations/ages: Heaven pushed up, sun released.

3. Current gods defeat/kill predecessors: killing the dragon, use of sacred drink.

4. Humans: somatic descendants of (sun) god; they (or a god) show hubris [and] are punished by a flood.

5. Trickster deities bring culture: humans spread (emergence of 'nobles').

6. Local history begins.

7. Final destruction of the world.

8. New heaven and Earth emerge.

We again see notions of a sky-father and several generations of sky-deity, consistent with observations of a progenitor comet and multiple cometary splitting events, which can obviously be associated with the Taurid meteor stream. Catastrophic events are also highlighted, including a cycle of world 'ages' and clearing of the 'heavens', which again are consistent with the notion of catastrophic interactions with the Taurid meteor stream. Also emphasized are 'trickster' deities and a dragon, or 'cosmic serpent'. Given the likely association of serpents with meteor tracks at Gobekli Tepe, the generalised 'cosmic serpent' theme also likely symbolises a comet. The trickster deity can, likewise be interpreted as a comet, with its unpredictable orbit and even more unpredictable catastrophic encounters.

Given this background in Palaeolithic cave art, and comparative linguistics and mythology, we can begin to understand how an ancient zodiac can have lasted for so long across such a wide area. Essentially, we can link the ancient zodiac to this ancient mythology and cave art. Indeed, astronomy, mythology and large-scale art are common bed-fellows in ancient cultures; the Ancient Egyptians are a prime example. Quite possibly, the extreme duration of an ancient mythology and associated art-forms can be explained in part in terms of the near-constant appearance of the stars and their patterns, the constellations. Moreover, the natural world is tuned to the seasons, so it should be no surprise if ancient human cultures took a great interest in the stars for tracking them.

This does not mean that this work supports hyper-diffusionism. What is proposed here, however, is that some core aspects of culture, including mythology and its associated art and astronomical knowledge, can be extremely diffused, more so even than language, essentially because they are mutually 
supportive, and perhaps because the stars are so relatively static and the catastrophic threat posed by the Taurid meteor stream was so long-lasting.

\section{Bibliography}

Aardsma, G. E. "New Radiocarbon Dates for the Reed Mat from the Cave of the Treasure, Israel." Radiocarbon 43 (2001): 1247-54.

Allentoft, M. E., M. Sikora, K. G. Sjogren, S. Rasmussen, M. Rasmussen, J. Stenderup, P. B. Damgaard, et al. "Population Genomics of Bronze Age Eurasia." Nature 522, no. 7555 (Jun 2015): 167-+.

Asher, D. J., and S. V. M. Clube. "Towards a Dynamical History of 'Proto-Encke'." Celestial Mechanics \& Dynamical Astronomy 69, no. 1-2 (1997): 149-70.

Asher, D.J., Clube S.V.M., Napier W.B., and Steel D.I. "Coherent Catastrophism." Vistas in Astronomy 38, no. 1 (1994): 1-27.

Barshay-Szmidt, C., S. Costamagno, D. Henry-Gambier, V. Laroulandie, J. M. Pétillon, Boudadi-Maligne, D. Kuntz, M. Langlais, and J. B. Mallye. "New Extensive Focused Ams $1^{4} \mathrm{C}$ Dating of the Middle and Upper Magdalenian of the Western Aquitaine/ Pyrenean Region of France (Ca. 19-14 ka cal bp): Proposing a New Model for Its Chronological Phases and for the Timing of Occupation." Quaternary International 414 (2016): 62-91.

Bomhard, A. A Comprehensive Introduction Ot Comparative Nostratic Linguistics. 2nd ed. 2015. doi:http:// independent.academia.edu/AllanBomhard.

Clube, S. V. M., and W. M. Napier. "The Microstructure of Terrestrial Catastrophism." Monthly Notices of the Royal Astronomical Society 211, no. 4 (1984): 953-68.

Clube, V., and W Napier. The Cosmic Serpent. London: Faber and Faber Limited, 1982.

Cummins, W. Decoding the Pictish Symbols. The History Press, 2009.

Dietrich, O., M. Heun, J. Notrofft, K. Schmidt, and M. Zarnkow. "The Role of Cult and Feasting in the Emergence of Neolithic Communities. New Evidence from Gobekli Tepe, South-Eastern Turkey." Antiquity 86, no. 333 (Sep 2012): 674-95.

Dolgopolsky, A. Nostratic Dictionary. McDonald Institute for Archaeological Research, 2008.

Edwards, K. J., and I. Ralston. "New Dating and Environmental Evidence from Burghead Fort, Moray." Proceedings of the Society of Antiquaries of Scotland 109 (1978): 202-10.

Firestone, R. B., A. West, J. P. Kennett, L. Becker, T. E. Bunch, Z. S. Revay, P. H. Schultz, et al. "Evidence for an Extraterrestrial Impact 12,900 Years Ago That Contributed to the Megafaunal Extinctions and the Younger Dryas Cooling." Proceedings of the National Academy of Sciences of the United States of America 104, no. 41 (Oct 2007): 16016-21.

Haak, W., I. Lazaridis, N. Patterson, N. Rohland, S. Mallick, B. Llamas, G. Brandt, et al. "Massive Migration from the Steppe Was a Source for Indo-European Languages in Europe." Nature 522, no. 7555 (Jun 2015): 207-+.

Hakenbeck, S. "Migration in Archaeology: Are We Nearly There Yet." Archaeological Review from Cambridge 23 (2008): 9-26.

Hart, G. The Routledge Dictionary of Egyptian Gods and Godesses. Routledge, 2005.

Hayden, B., and S. Villeneuv. "Astronomy in the Upper Palaeolithic." Cambridge Archaeological Journal 21 (2011): 331-35. 
Hendrickx, S., and R. Friedman. "Gebel Tjauti Rock Inscriptions I and the Relationship between Abydos and Hierakonpolis During the Naqada Iii Period." Gottinger Miszellen 196 (2003).

Hodder, I. Catalhoyuk: The Leopard's Tale: Revealing the Mysteries of Turkey's Ancient 'Town'. London: Thames and Hudson Ltd., 2011.

Holliday, V. T., T. Surovell, D. J. Meltzer, D. K. Grayson, and M. Boslough. "The Younger Dryas Impact Hypothesis: A Cosmic Catastrophe." Journal of Quaternary Science 29, no. 6 (Aug 2014): 515-30.

Jackson, A. The Symbol Stones of Scotland. Orkney, 1984.

Kaul, F. "The Gundestrup Cauldron: Thracian Art, Celtic Motifs." Etudes Celtiques 37 (2011): 81-110.

Kennett, J. P., D. J. Kennett, B. J. Culleton, J. E. A. Tortosa, J. L. Bischoff, T. E. Bunch, I. R. Daniel, et al. "Bayesian Chronological Analyses Consistent with Synchronous Age of 12,835-12,735 Cal Bp for Younger Dryas Boundary on Four Continents." Proceedings of the National Academy of Sciences of the United States of America 112, no. 32 (Aug 2015): E4344-E53.

Kenoyer, M. J. "The Indus Valley Tradition of Pakistan and Western India." Journal of World Prehistory 5 (1991): 331-85.

Le Quellec, J.L, and D. Huyge. "Rock Art Research in Egypt, 2000 - 2004." Chap. 5 In Rock Art Studies, News of the World Iii, edited by P.G. Bahn, N. Franklin and M. Strecker. Oxford: Oxbow Books, 2008.

Lee, R., P. Jonathan, and P. Ziman. "Pictish Symbols Revealed as a Written Language through Application of Shannon Entropy." Proceedings of the Royal Society A 466 (2010): 2545-60.

Lull, J., and J. A. Belmonte. "The Firmament above Thebes: Uncovering the Constellations of Ancient Egyptians." Journal for the History of Astronomy XXXVII (2006): 1-20.

Mack, A. A Field Guide to the Pictish Symbol Stones. The Pinkfoot Press, 1997.

Mackenzie, D. Egyptian Myths and Legends. Gresham Publishing Co., 1907.

Magli, Giulio. "Astronomy and Architecture at the Roots of Civilization." In Archaeoastronomy, 53-74: Springer, 2016.

Mallory, J.P., and J.Q. Adams. The Oxford Introduction to Proto-Indo-European and the ProtoIndo-European World. Oxford University Press, 2006.

Milevski, L. "A New Fertility Figurine and New Animal Motifs from the Chalcolithic in the Southern Levant : Finds from Cave K-1 at Quleh, Israel." Paleorient 28 (2002): 13341.

Nielsen, S., J. H. Andersen , J. A. Baker , C. Christensen , J. Glastrup , P. M. Grootes , M. Hüls, et al. "The Gundestrup Cauldron: New Scientific and Technical Investigations." Acta Achaeologica 76 (2005): 1-58.

Noble, G., and N. Evans, eds. The King in the North: Birlinn Ltd., 2019.

Notroff, J., O. Dietrich, L. Clare, and et al. "More Than a Vulture: A Response to Sweatman and Tsikritsis." Mediterranean Archaeology and Archaeometry 17, no. 2 (2017): 57-63.

Olsen, B. A., T. Olander, and K. Kristiansen, eds. Tracing the Indo-Europeans: Oxbow Books, 2019.

Reimer, P.J., E. Bard, A. Bayliss, and J.W. Beck. "Intcal13 and Marine13 Radiocarbon Age Calibration Curves 0-50,000 Years Cal Bp." Radiocarbon 55 (2013): 1869-87.

Renfrew, A.C., ed. Nostratic: Examining a Nostratic Macrofamily: McDonald Institute for Archaeological Research, 1999. 
Rogers, JH. "Origins of the Ancient Constellations: 1. The Ancient Mesopotamian Traditions." Journal of the British Astronomical Society 108, no. 1 (1998): 9-28.

Shaw, I. The Oxford History of Ancient Egypt. Oxford University Press, 2000.

"Stellarium 0.18.0." http://stellarium.org/.

Storey, E. A., and T. L. Jones. "Diffusionism in Archaeological Theory." In Polynesians in America: Pre-Columbian Contacts with the New World, edited by T. L.Storey Jones, E. A., E. A. Matisoo-Smith and J. M. Ramirez-Aliaga: Altamira Press, 2011.

Sweatman, M. B. Prehistory Decoded. Matador, 2019.

Sweatman, M. B., and A. Coombs. "Decoding European Palaeolithic Art: Extremely Ancient Knowledge of Precession of the Equinoxes." Athens Journal of History 5, no. 1 (2019): 1-30.

Sweatman, M.B, and D. Tsikritsis. "Decoding Gobekli Tepe with Archaeoastronomy: What Does the Fox Say?". Mediterranean Archaeology and Archaeometry 17, no. 1 (2017): 23350.

Sweatman, M.B. "Catastrophism through the Ages, and a Cosmic Catastrophe at the Origin of Civilisation." Archaeology and Anthropology Open Access 1, no. 2 (2017).

Ussishkin, D. "The Chalcolithic Temple in Ein Gedi: Fifty Years after Its Discovery." Near Eastern Archaeology 77 (2014): 15-26.

Witzel, E.J.M. The Origins of the World's Mythologies. Oxford: Oxford University Press, 2012. 
